Guest Editorial, part of a Special Feature on Implementing Participatory Water Management: Recent Advances in Theory, Practice and Evaluation

\title{
Implementing Participatory Water Management: Recent Advances in Theory, Practice, and Evaluation
}

\author{
Yorck von Korff $^{1,2}, \underline{\text { Katherine A. Daniell }}^{2,3}, \underline{\text { Sabine Moellenkamp }}^{4}, \underline{\text { Pieter Bots }}^{5}$, and $\underline{\text { Rianne M. Bijlsma }}^{6,7}$
}

\begin{abstract}
Many current water planning and management problems are riddled with high levels of complexity, uncertainty, and conflict, so-called "messes" or "wicked problems." The realization that there is a need to consider a wide variety of values, knowledge, and perspectives in a collaborative decision making process has led to a multitude of new methods and processes being proposed to aid water planning and management, which include participatory forms of modeling, planning, and decision aiding processes. However, despite extensive scientific discussions, scholars have largely been unable to provide satisfactory responses to two pivotal questions: (1) What are the benefits of using participatory approaches?; (2) How exactly should these approaches be implemented in complex social-ecological settings to realize these potential benefits? In the study of developing social-ecological system sustainability, the first two questions lead to a third one that extends beyond the one-time application of participatory approaches for water management: (3) How can participatory approaches be most appropriately used to encourage transition to more sustainable ecological, social, and political regimes in different cultural and spatial contexts? The answer to this question is equally open. This special feature on participatory water management attempts to propose responses to these three questions by outlining recent advances in theory, practice, and evaluation related to the implementation of participatory water management. The feature is largely based on an extensive range of case studies that have been implemented and analyzed by cross-disciplinary research teams in collaboration with practitioners, and in a number of cases in close cooperation with policy makers and other interested parties such as farmers, fishermen, environmentalists, and the wider public.
\end{abstract}

Key Words: adaptive management, collaborative decision making, evaluation, interactive planning, participatory modeling, participatory research, process design, public participation, social learning, stakeholder participation, water resources management

\section{FOCUS AND OBJECTIVES OF THE SPECIAL FEATURE}

Many current water planning and management problems are riddled with high levels of complexity, uncertainty, and conflict, so-called "messes" (Ackoff 1979) or "wicked problems" (Rittel and Webber 1973). These problems are increasingly encountered in the public policy sphere as resources become scarce, conflicts between water users and interest groups proliferate, and the ecological and social aspects of water planning become more prominent. As a result, it is increasingly rare that technical water managers have sufficient decision making authority and capacity to implement plans and water management actions by themselves. Furthermore, the realization that there is a need to consider a wide variety of values, knowledge, and perspectives in a collaborative decision making process has led to a multitude of new methods and processes being proposed to aid water planning and management (e.g., Creighton 2005, HarmoniCOP 2005, Mostert et al. 2007), which include participatory forms of modeling, planning, and decision aiding processes (e.g., Hare et al. 2003, Bryson 2004).
We use the term "participatory" here to refer in general to processes that actively involve not only water managers and government officials, but also other interested parties. An increasing uptake of participatory approaches and methods has occurred not only in water management, but also in other public policy fields such as urban planning, health, and technology risk assessment. However, despite extensive scientific discussions, scholars have largely been unable to provide satisfactory responses to two pivotal questions (Webler and Tuler 2001): (1) What are the benefits of using participatory approaches?; (2) How exactly should these approaches be implemented in complex social-ecological settings to realize these potential benefits?

These questions are not only of interest to the scientific community but equally to water managers and policy makers. The lack of clear understanding related to these questions means that in many cases the potential for effective water management remains unattained (see for example, Borowski et al. 2008).

In the study of developing social-ecological system sustainability, the first two questions lead to a third one that

\footnotetext{
${ }^{1}$ Lisode, ${ }^{2}$ Cemagref / Irstea UMR G-EAU, ${ }^{3}$ The Australian National University, ${ }^{4}$ University of Osnabrueck, ${ }^{5}$ Delft University of Technology, ${ }^{6}$ University of Twente, ${ }^{7}$ Deltares
} 
extends beyond the one-time application of participatory approaches for water management: (3) How can participatory approaches be most appropriately used to encourage transition to more sustainable ecological, social, and political regimes in different cultural and spatial contexts (Stringer et al. 2006)?

The answer to this question is equally open. The idea of participation leading to more sustainable regimes (see for example, Lebel et al. 2006, Tàbara and Pahl-Wostl 2007) is of urgent practical relevance given the increasingly perceived scarcity and fragility of water resources around the world (Rijsberman 2006, UNDP 2006, example case studies in Walker and Salt 2006).

This special feature on participatory water management attempts to propose responses to these three questions by outlining recent advances in theory, practice, and evaluation related to the implementation of participatory water management. The feature is largely based on an extensive range of case studies that have been implemented and analyzed by cross-disciplinary research teams in collaboration with practitioners, and in a number of cases in close cooperation with policy makers and other interested parties such as farmers, fishermen, environmentalists, and the wider public. We outline the findings from the literature related to the three questions and then specify how the articles in this special feature contribute to responding further to them. Finally, we summarize the achievements of the special feature and identify questions and directions for future research.

\section{ADVANCES AND TRENDS IN PARTICIPATION RESEARCH}

The field that we call "participation research" is largely heterogeneous, because research on participation has developed from many different thematic interests, ranging from health care and urban planning to environmental management and information technology development, and has also been found scattered through a range of disciplines including political science, sociology, social-psychology, as well as engineering, architecture, and management. Now, over 40 years after Arnstein's (1969) much quoted article on participation, the field of research is maturing. We are now at the stage in which some responses to our focal questions have been provided, and across the various thematic foci and original disciplines of the field, a number of new research strands are evolving. For each of our three focal questions, we first give a general overview of its treatment in the literature and then present crosscutting research trends that show current movements in participation research. We then also summarize which articles in this special feature touch upon these trends and/or develop them further.

\section{Question 1: research on benefits of participation} Overview

Scholars such as Fiorino (1990), Laird (1993), Renn et al. (1995), or Beierle and Cayford (2002) have identified various benefits of participation ranging from increased legitimacy of decisions, to the development of participatory democracy, in addition to representative democracy. Some of these and other benefits occur as a product of learning. During interaction, participants learn about the issues discussed and others' points of view. They are also able to discover new common ground and to enhance their social interaction skills. As a result of this learning, the following benefits are ascribed to participation:

- Better quality decisions: When the knowledge of different actors, including experts, is brought together and integrated during discourse, this can potentially lead to better informed decisions.

- Better acceptance of decisions: By involving people who are affected by the decision, broader agreement can be sought, which will potentially increase support for implementation.

- Development of social capital: Through the potentially intensive interaction in a participation process, participants can build new networks and work to resolve conflicts, thus having an opportunity to increase their social capital, which in turn may enable them to more easily solve problems and new conflicts in the future.

\section{Trend: evaluation of participation}

For more than a decade, major policies, such as the 2000 European Water Framework Directive, and the terms of reference for many projects, in particular in the development sector, have required different forms of stakeholder involvement and participation. In an attempt to identify to what extent these policies and projects are producing the theoretical benefits of participation, authors have proposed a range of evaluation procedures. For example, sets of criteria have been developed to analyze the influence of the political, economic, and social context of participation (e.g., Beierle and Konisky 2000). Other frameworks have been developed to evaluate the quality of the participation process (e.g., Webler 1995, Rowe and Frewer 2000, Schuett et al. 2001). Result evaluations of individual cases (e.g., Rowe et al. 2004) but also of long-term and large-scale participation approaches have also been carried out (e.g., for an evaluation of the international governance approach in the North American Great Lakes region, see Klinke 2009), as well as meta evaluations based on multiple case studies (e.g., Beierle and Cayford 2002, Jones et al. 2009, Newig and Fritsch 2009, Etienne 2010). Despite this progress, empirical data are still largely inconclusive as to under which conditions participation typically leads to 
social learning, that is to say "a process of communicative action where multiple actors collectively learn about and develop an understanding of each other's interests, concerns, and preferences through dialog and deliberation" (Muro and Jeffrey 2012). Also of continuing major importance is the question of to what extent "participative processes actually contribute to an improved implementation of environmental policy and thus to a more sustainable usage of the environment" (Newig 2007:52, see also Newig and Fritsch 2009).

\section{Discussion in this feature}

Almost all of the authors of the special feature address evaluation of participation in some way. For example, Barreteau et al. (2010) present a framework to clarify what participation entails when involving stakeholders in research. The framework specifies the timing of participation in the policy process, participants' control over information, and clarifying the setting in which participant interactions take place. The authors argue that clarifying these three dimensions provides a frame for tracking the research process so that ex post assessment or comparison of the participatory elements of the process is possible.

Looking at a groundwater conflict case in the eastern Netherlands, Bijlsma et al. (2011) address questions of evaluation in two ways: first, they propose an original evaluation design, and second, they propose a new research variable in the evaluation of participatory processes. In their paper, the authors compare two processes of policy development, one expert-based and one stakeholder-based, both for the same case study. Within the evaluation design for their "with-and-without-participation" comparison, the authors introduce the new variable of the actors' handling of uncertainty. The authors show that uncertainty handling, aimed at stimulating actors' tolerance levels to work with uncertainty and at developing approaches to work toward reducing uncertainty, took different forms in the expert and stakeholder-based processes.

Like Barreteau et al. (2010), Bots et al. (2011) provide guidelines for model use in participatory settings that could be used as an evaluation tool to track down the informal rules for interaction between participants in a participatory process. Their approach may serve as a coding scheme to facilitate detailed cross-case comparison of participatory process designs.

Huitema et al. (2010) measure the depth of learning of policy makers and citizens occurring as a result of being involved in a specific participatory approach: citizen juries. Their article focuses on three citizen juries in the Dutch part of the Rhine basin and introduces an original method to assess the depth of participants' cognitive, normative, and relational learning. The method could, as the authors claim, also be used for other participatory approaches.
Several author teams (Kuper et al. 2009, Zorilla et al. 2009, Daniell et al. 2010, Hirsch et al. 2010, Lamers et al. 2010, Moellenkamp et al. 2010, Selman et al. 2010, Hoverman et al. 2011) provide a detailed description of the framework they applied for evaluating the process management, output, and/ or outcome of the participatory approach in their case studies. Kuper et al. (2009) specifically relate their outcome evaluation to the socioeconomic context present in their case study, the situation of small-scale farmers in central Morocco, and speculate on longer term effects of the participatory activities.

\section{Trend: participation and (social) learning}

Research on social learning in participatory water management commonly stems, at least in Europe, from Bandura's concept of social imitation and modeling (Bandura and Walters 1963, Bandura 1977), as well as Habermas's concept of communicative action (Habermas 1987). Researchers focusing on this latter concept (e.g., Röling 2002, SLIM Project 2004, Ridder et al. 2005, Tàbara and Pahl-Wostl 2007, Pahl-Wostl et al. 2008a) are interested in what happens as a result of information exchanges among actors in participatory processes in terms of their understanding of the natural and social systems, i.e., cognitive learning, the quality of their relationships, their skills, for example, to participate constructively in a debate or negotiation, and their willingness and ability to reach a consensus.

Another current in the social learning literature focuses more on practical application. Early works by Lewin (1939) on factors that influence group dynamics and by Rogers (e.g., 1961) on group leader characteristics that facilitate learning, have been followed by many studies in the organization and management sciences on how to practically help professionals to be more effective in their learning, for example, by using open feedback processes (e.g., Argyris 1993, Senge et al. 1994, 1999, Schein 1999).

There has been some cross-fertilization between the two strands of literature, for example, with U.S.- and Europe-based water management researchers developing applications of Habermas's concepts together (e.g., Renn et al. 1995) and European researchers taking note of the current influence of Lewin and Rogers (e.g., Pahl-Wostl et al. 2007). An open question remains as to what extent the various social learning concepts and applications can be translated into practice in natural resources management processes. This is of particular importance because social learning is in many cases not yet on the agenda of water managers and because many of the applications, for example, reflections of a group on its performance, are psychologically and culturally difficult tasks in many settings (also see Huitema et al. 2009). 


\section{Discussion in this feature}

Many of the authors in this feature reflect on social learning related to a variety of aspects of participatory processes. For example, Hoverman et al. (2011) demonstrate how social learning can occur in a small island postconflict developing state, the Solomon Islands, and how far the participants of their case study have shown themselves to be receptive to engaging in social learning. Their work also highlights that participatory processes in developing countries can assist in the creation of trusting relationships between traditional societies and water management planners. Despite historical difficulties, through the use of bridging individuals, participants were generally able to transcend the constraints of their individual knowledge cultures, expand systems for integrated water resources management, and envisage new opportunities for productively working together.

Huitema et al. (2010) focus specifically on evaluating the social learning effects of citizens' juries in the Netherlands. Through their analyses, they find high levels of cognitive, normative, and relational levels of learning for the participants of the citizen juries, but relatively low levels of learning for policy makers. They also analyze the reason for this divergence.

Kuper et al. (2009) describe the application of participatory methods in a central Moroccan context to support small-scale farmers in designing a joint drip irrigation project. The authors outline and evaluate their experiences in developing a social learning environment to enhance the capacity of the farmers who manage the projects. Based on the new-build capacity, farmers could decide for themselves on the adoption of drip irrigation, influenced by socioeconomic as well as technological considerations.

Moellenkamp et al. (2010) explore the interplay of informal and formal settings in a participatory process in the German Dhünn river basin, a tributary to the Rhine. The authors argue that niches for the establishment of informal participatory platforms, which facilitate exchange and social learning, can occur even in a rigid and strongly structured administrative environment. The authors conclude that, for an effective participatory process, a balance should be struck between informality on the one hand, so that a collective identity and change in perception can be achieved, thus allowing a maximum of experimentation and learning, and formality on the other hand, ensuring that the process has an impact in practice.

Selman et al. (2010) implicitly touch on the concept of social learning through their exploration of a much less discussed participatory method called imaginative engagement, the use of art-based methods to involve people more actively in reflecting on and identifying with their catchment. They were exploring to what extent these methods can help in raising catchment consciousness, contribute to changes in values, knowledge, and personal action, and even help in raising social and institutional capacity for contributing to the sustainable development of river basins. Their case study focuses on a postindustrial area of South Yorkshire in the UK and more specifically a $20 \mathrm{~km}$ stretch of the valley of the River Dearne, once an area at the heart of the UK's coal mining and steelmaking industries and today in the search of a new identity.

Zorilla et al. (2009) show how the co-construction of models can be used to facilitate participatory processes and to generate learning. They focus on an experience of constructing Bayesian networks with stakeholders from the Upper Guadiana Basin in central Spain, where uncontrolled groundwater extraction is responsible for wetland degradation and conflicts between farmers, water authorities, and environmentalists. The authors argue that the modeling activities contributed to a better understanding of the different elements of the system and their interrelations, including other stakeholders' concerns.

\section{Question 2: research on implementation of participation Overview}

Many scholars have pointed to the fact that the expected benefits of participation do not occur automatically, and that participation processes can "go wrong" if they are not competently designed and implemented (Brett 1996, Stern and Fineberg 1996, Coglianese 1997, Webler 1999, Delli Carpini et al. 2004, Irvin and Stansbury 2004). At the same time, it must be noted that considerable advice has been created either in the form of practical guidelines for the managers of participation processes (e.g., Creighton 2005), numerous case study examples (Carr and Halvorsen 2001, Webler and Tuler 2001, Beierle and Cayford 2002, Rowe et al. 2004, Klinke 2009), elaborations of the concept of participation (e.g., Arnstein 1969, Pateman 1970, Webler and Renn 1995, Mostert 2003, Delli Priscoli 2004, Newig 2005), or in the form of research that usually focuses on the question of what are the criteria of "good" or "effective" participation processes (e.g., Rowe and Frewer 2000, Beierle and Cayford 2002, Dietz and Stern 2008). Despite these achievements, the question of which participatory approach to choose in which particular setting or context remains very much on the agenda (Rosenhead and Mingers 2001, Rowe et al. 2004). This remaining difficulty is also illustrated by the fact that many water and natural resources managers throughout Europe and beyond still lack experience with the implementation of interactive stakeholder participation processes (Pahl-Wostl et al. 2008b) or feel uncomfortable with it (Daniell et al. 2010).

\section{Trend: design of participation processes}

Systematic research on the design of participation is a young and emerging research field. We note here two key strands: 
one that is rooted in evaluation research and the other that stems from design practice.

A number of evaluation researchers have focused their interest on criteria for "good" or "effective" participation processes (Webler 1995, Rowe and Frewer 2000, Syme and Nancarrow 2002, Marks 2004, Rowe and Frewer 2004), which can be of interest for participation process designers. For example, Rowe et al. (2001) suggest that their nine criteria for "effective" participation processes, e.g., representativeness of selected participants or unbiasedness of the process, can also be used "a priori to ensure the effectiveness of an exercise application" (italics in original). Similarly, Webler (1995) in a much cited work on evaluating discourse, proposed a comprehensive set of detailed rules and subrules that can be used to shape design. Recognizing that different political and social contexts require different process designs, some evaluation researchers have set up a research agenda that is attempting to systematically categorize participation contexts and match them to different types of processes (Rowe and Frewer 2004).

The second strand of design research is just emerging. Considerable work on how to design participation processes has been done by participation practitioners, and not by researchers. These have recorded their insights in practical design guides. These guides often seek to orientate process design in varying contexts by providing general principles, typical design phases, and questions that the designers should ask in these different phases (Stern and Fineberg 1996, Beierle and Cayford 2002, Creighton 2005, Mazri 2007; P. d'Aquino, unpublished manuscript). Until recently, this work was mostly ignored in the scientific literature. However, Webler (1999) mentioned potential benefits of a research-practitioner dialogue and in this special feature von Korff et al. (2010) begin to systematically review the practitioner knowledge embedded within the design guides.

\section{Discussion in this feature}

Design of participation processes is treated in a number of ways in this special feature. For example, the framework of Barreteau et al. (2010) helps not only to track how a participation process is carried out but also to clarify how communication with stakeholders should be organized in the implementation of participatory research. They argue that potential disappointment experienced by stakeholders, and eventually researchers and policy makers, can be avoided by being upfront and precise about how the process will be implemented, and what kind of involvement is expected from participants.

Daniell et al. (2010) reflect on the collective construction, or "co-engineering", of two multilevel participatory water management processes in Australia and Bulgaria. By doing so, they introduce a rarely discussed aspect of participation processes, namely the analysis of the social interactions, conflicts, and negotiations in the project team that designs and implements these processes. They then also evaluate how these interactions in co-engineering processes influence the participation processes with stakeholders and their outcomes.

Hirsch et al. (2010) describe how participatory research projects can be conducted in the political and cultural context of Uzbekistan, which usually provides little room for stakeholder participation. They illustrate the choices behind, and application of, different participatory methods and their adaptation to the given environment, the usefulness of these methods in improving system understanding and developing strategies and measures to improve water management and monitoring, and the acceptance and suitability of these methods for enhancing policy making processes in the Amudarya River basin context.

Huitema et al. (2010) feed into the discussion on how participatory water management could be designed, namely in the form of citizen juries, and what aspects of designing citizen juries, and possibly other participation processes as well, may be essential for enhancing social learning.

Lamers et al. (2010) describe the construction of an interactive decision process in the Dutch Rhine basin. The process is based on involving stakeholders at various degrees, using a "bull's eye approach," based on their interest or stake in the process and also their decision authority. An important process element in this case seems to have been a midterm reflection workshop in which, in the spirit of adaptive management, lessons learned were drawn and the process subsequently adjusted.

Moellenkamp et al. (2010) explore to what extent collaborative process design, by a so-called "trialogue team" of water association, researchers, and consultants, enabled the reduction of uncertainties by making use of knowledge and expertise of the collaboration partners and by externalizing parts of the uncertainties from one partner to another.

von Korff et al. (2010) also contribute directly to expanding this field of research by addressing the question of how to design participation processes. They focus on practitioners' design guides, an area that has received little attention in the participation research literature. The authors thus introduce knowledge from the so-called 'craft' literature into the scientific debate. They systematically analyze and compare five design guides of the craft literature to combine them into a scientifically more robust guide for designing participation processes. They challenge the recent research approach on design that asks what type of method to apply in what type of context. Instead, the authors are encouraging water managers to follow an iterative and adaptive learning path throughout design and thus, together with the stakeholders, to develop an appropriate process for the water management context. 


\section{Trend: participation in modeling}

Issues of stakeholder participation linked to modeling for water management and other domains have increasingly been receiving interest from researchers and water managers alike. The increasing difficulty for managers to come to widely supported decisions if stakeholder interests are not taken into account in modeling, and to build increased understanding of water and their linked socio-ecological systems, have been a significant driver of this interest (Daniell and Ferrand 2006, Jakeman et al. 2006, Voinov and Bousquet 2010). This has led to the development of different methodologies for involving stakeholders in participatory forms of modeling for water management, including shared vision modeling (Werick and Whipple, Jr. 1994), group model building (Vennix 1996, Pahl-Wostl and Hare 2004), mediated modeling (van den Belt 2004), and companion modeling (Bousquet et al. 1996, Barreteau 2003). Some of these appear to aid the building of consensus for taking water management decisions, e.g., shared vision modeling, or mapping out diversity of points of view and enhancing stakeholder learning, e.g., companion modeling. Recent trends in the field of participatory forms of modeling have headed in a number of directions including determining what role modeling can play in decision aiding activities (Loucks et al. 1985, Hatchuel and Molet 1986, Costanza and Ruth 1998, Belton and Stewart 2002, Daniell et al. 2006), what methods are most adapted to different contexts (Flood and Jackson 1991, Midgley 1997, Mingers 2001), evaluating the effects and outcomes of participatory modeling exercises (Hare et al. 2003, Jones et al. 2009, Etienne 2010), and determining who organizes, chooses, and influences the modeling process, and what specific roles they play (LunaReyes et al. 2006).

\section{Discussion in this feature}

A number of authors in the special feature link to this trend of involving stakeholders in modeling. For example, based on a case study in the eastern Netherlands that involved a conflict around the choice of a hydrological model, Bots et al. (2011) propose a code of conduct for the interaction between actors involved in a participatory modeling process, using an existing model presented in the form of a set of "rules of the game." The rules address the organization of a process and may serve as a guide in the design of future participatory modeling processes. Bots et al. (2011) also illustrate the importance of information sharing, including on the limitations of existing models, e.g., uncertainties.

Daniell et al. (2010) deepen the work on determining who organizes and influences the modeling process, and what specific roles they play in the project team or "co-engineering" process that makes the organizational decisions related to participatory modeling processes. They show that predefined participatory modeling methodologies are unlikely to be directly applied in particular cases, but that they will likely be renegotiated with a variety of people, including stakeholders, both prior to and during their implementation.

Zorilla et al. (2009) describe how Bayesian network models can be used as a participatory tool to further dialogue and to gain a shared stakeholder understanding in a conflict ridden setting, namely the overexploitation of groundwater resources in central Spain. The evaluation was predominantly positive, demonstrating that participants valued the method for structuring the discussion and enhancing system understanding.

\section{Trend: participatory action as part of the research}

Researchers first setting up, or contributing to the set-up, of participatory actions and then evaluating them find their roots in action and activist research, where researchers intervene to drive social and political change (Lewin 1951, Argyris et al. 1985, Heron 1996, Flood 1998, Freire 2003). Recent trends in participatory research practice and research on participatory processes include a reassessment of their epistemological foundations (Reason and Torbert 2001, Hatchuel 2005), creation of typologies (Cornwall and Jewkes 1995, Probst and Hagmann 2003), ethics (Cahill et al. 2007, Sultana 2007), and movement toward a range of pluralist perspectives on research philosophy, theory, and method (Gregory 1996, Taket and White 1996, Midgley 2000, Mingers 2003), which is linked to reflection on the position of the researcher and other actors in participatory water management. Maybe most apparent, however, is a trend among many researchers to become active as change managers and facilitate the implementation of participation methods.

\section{Discussion in this feature}

This last trend, i.e., researchers as interveners in participation, is strongly represented in this feature. Most author teams of this feature represent this hybrid: contributing to a participatory process and drawing lessons from it as well. For example Daniell et al. (2010; for the Bulgarian process), Hirsch et al. (2010), Hoverman et al. (2011), Kuper et al. (2009), Selman et al. (2010), and Zorilla et al. (2009) initiated, and carried out, their respective processes, i.e., without them the processes would not have existed. The researcher and practitioner teams outlined in Bijlsma et al. (2011), Bots et al. (2011), Daniell et al. (2010; for the Australian process), Lamers et al. (2010), and Moellenkamp et al. (2010) advised or co-constructed their respective processes with water managers or facilitated meetings through the processes. This raises questions, as, for example, addressed by Barreteau et al. (2010), of how researchers need to clarify their objectives and roles in participation processes, as well as the potential benefits of research-driven versus management-driven participation processes for water management as discussed in Daniell et al. (2010). 
Question 3: participation as an instrument for institutional, social, and ecological change

\section{Overview}

With regard to the third question of this feature, a recent article in this journal suggested that one means of developing and sustaining desired ecological, social, and political states is through the practice of stakeholder involvement and public participation (Enserink et al. 2007). These authors state specifically that "[p]ublic participation is both a prerequisite and an element of good governance and the sustainable management of natural resources." In a similar vein, other authors have associated participation with sustainability (Johnson 1997, Ostrom 1990) and greater adaptive capacity of social-ecological systems (Pahl-Wostl 2007). The role of participation may then be considered as one of a vehicle of transition to more sustainable ecological, social, and political regimes, as well as an ongoing part of management processes once the transition has been achieved.

\section{Trend: participation and adaptive management}

As an instrument of change, participation plays a central role in the current discussion on the concept of adaptive management. Adaptive management can be considered as a systematic process for improving management policies and practices by learning from the outcomes of implemented management strategies (Walters 1986, Lee 1993, 1999). While explicitly acknowledging uncertainty and complexity (see also Berkes and Folke 1998), the concept stresses the ability of readjustment to changes in the system being managed (also see Gunderson and Holling 2001). Researchers working with this concept (such as Berkes and Folke 1998, Stringer et al. 2006, Pahl-Wostl 2007) focus on participation as a basis for learning processes and creative solutions (see Folke et al. 2005). Broadening the scope of possible management strategies by including different interests and stakeholder groups helps policy makers to develop flexible ways of managing the environment (also see Stringer et al. 2006 ). The use of participation within the concept of adaptive management is closely linked to the concept of social learning, emphasizing collaboration and the development of shared practices between different stakeholders to respond flexibly to unexpected developments, and to include new insights and changing circumstances into management decisions (see also Fiorino 1990).

\section{Discussion in this feature}

Several articles refer to the concept of adaptive management and the importance of participation processes to support to it. For example, Hirsch et al. (2010) explore the implementation of participatory methods, i.e., nominal group technique, community-based research, cognitive mapping, group model building, strategic choice approach, and role-playing games, in the Uzbek policy context of top-down water management, to enable more adaptive forms of natural resources management. The authors show that participation contributed to an improved system understanding and, arguably, learning among both stakeholders and local researchers and thus to a core component of adaptive management.

Investigating the development of adaptive management processes in more detail, Lamers et al. (2010) argue that a careful process design, a thorough and continuous stakeholder analysis, building reflective workshops within and after the process, and ensuring experienced and qualified process leaders can greatly enhance the adaptive capacity and successful outcome of the participatory planning process.

The article by Méndez et al. (2012) describes in rich detail a case study and historical analysis of the development of a rigid institutional regime for water management and wetland conservation in Spain's Guadalquivir estuary, along with how transition to a more flexible and adaptive regime might be facilitated in the future through the development of action research and participation processes.

Finally, Moellenkamp et al. (2010) analyze the interplay of informality and formality of a participatory process for adaptive management. They deal with three major challenges related to this interplay. First, the niche finding process, i.e., introducing an informal process into a strongly structured administrative environment; second, the process of co-design of the participation process; and third, the outcomes in terms of tangible outputs and social learning. They show that a certain degree of informality is important for catalyzing experimentation and change.

\section{Trend: participation and development}

Since the 1970s, participation has played a role in rural development concepts (Belshaw and Chambers 1973, Uphoff et al. 1979). In the 1990s, participatory technology development approaches also noted the value of local knowledge, and that it should be integrated into the development of innovative solutions (Röling 1996, Biggs and Smith 1998). Specifically, Chambers (1994) emphasized the importance of local capacity building, knowledge ownership, and empowerment, if local end users were to adopt the proposed solutions. These ideas were taken a step further with the research of Ostrom et al. $(1990,1999)$, who suggested that local communities throughout the world may in many cases be able to successfully manage their own resources without the need for centralized authorities to take local decisions. Today we can see a widespread application of participatory approaches in many areas of development research and practice. However, big challenges still remain in many cases to support transitions from centralized resource management regimes to more decentralized regimes, as well as to develop the skillful application of participatory approaches in practice (Creighton 2005). We note that even though this trend is listed 
under the question of participation and change, it also closely relates to other themes already outlined under the first two questions on: "What are the benefits of using participatory approaches?" and "How exactly should these approaches be implemented in complex social-ecological settings to realize these potential benefits?"

\section{Discussion in this feature}

As noted previously, Hirsch et al. (2010) reflect on the applications of participatory research methods in the Uzbek (Amudarya) water management context. They conclude that the stakeholder process provided an opportunity for meetings and discussions among stakeholders from different organizational levels and thus promoted communication between different levels and organizations, and that in a context where most stakeholders are not generally involved in policy making, there is a danger of raising expectations that a research project cannot meet, e.g., of transferring local interests to higher levels.

Hoverman et al. (2011) show how integrated water resources management (IWRM) in the Solomon Islands is supported by fostering stakeholders' understanding of system complexity, recognition of mutual dependence, appreciation of others' perspectives, and development of the capacity to work together and to create mutual trust. The researchers explored issues of transparency, trust, accountability, and mutual responsibility in discursive spaces. Despite historical difficulties, through the use of bridging individuals, participants of this study were generally able to transcend the constraints of their individual knowledge cultures, expand awareness and appreciation of the complexity of humanenvironment systems for IWRM, and envisage new opportunities for productively working together in integrated catchment management.

Finally, Kuper et al. (2009) contribute to this trend through their work of the joint design of shared drip irrigation projects among four groups of smallholder farmers in central Morocco. The authors describe how they designed a series of iterative and interactive participation activities that included farmer to farmer visits and role playing games, to support the farmers to better understand the implications of the design of their own joint drip irrigation projects. The authors finally speculate that such joint conversions to drip irrigation may provide an opportunity to evolve toward more sustainable forms to manage common water resources.

\section{CONCLUSION}

This special feature brings together a number of advances in research on participation in general and on participatory water management in particular. Concerning participation in general it:

- presents a wide variety of methods with case study examples of how to evaluate the benefits of participation;
- largely confirms the positive relationship between the adequate involvement of stakeholders and social learning outcomes;

- provides multiple advances on the design of participation processes with reflections on the social aspects of design team processes, design of participation in authoritarian contexts, and the introduction of previously neglected practitioner knowledge into the scientific debate;

- makes progress on the specific questions of how models can be used as a means of supporting stakeholder dialogue, as well as how models can be used to develop stakeholder acceptance of management solutions; and

- illustrates many cases of action research, and their evaluation, and reflects on how this can be effectively carried out.

Concerning the relationship between participation and water and natural resources management, this special feature:

- illustrates the relationship between specific process designs, for example, finding a balance between formal and informal elements, and adaptive capacity;

- investigates the opportunities of participatory water management in different contexts, including authoritarian or rigid regimes and in high, middle, and low-income countries; and

- shows that it is possible to respond to the various requirements in water management with a great variety of approaches ranging from the co-construction of formal Bayesian networks to artistic and creative approaches such as imaginative involvement.

Responses to this article can be read online at: http://www.ecologyandsociety.org/voll7/iss1/art30/ responses/

\section{Acknowledgments:}

This special feature and most of the authors carried out work as part of the Integrated Projects NeWater (contract 511179 GOCE) and AquaStress (contract 511231-2 GOCE). We would like to thank the European Commission for their financial support under the 6th EU Framework Programme for Research and Technological Development (FP6). We further thank all contributing authors for their efforts and enthusiasm in developing this special feature with us.

\section{LITERATURE CITED}

Ackoff, R. L. 1979. The future of operational research is past. Journal of the Operational Research Society 30(2):93-104. 
Argyris, C. 1993. Knowledge for action: a guide to overcoming barriers to organizational change. Jossey-Bass, San Francisco, California, USA.

Argyris, C., R. Putnam, and D. MacLain-Smith. 1985. Action science: concepts, methods and skills for research and intervention. Jossey-Bass, San Francisco, California, USA.

Arnstein, S. R. 1969. A ladder of citizen participation. Journal of the American Institute of Planners 35(4):216-224. http://dx .doi.org/10.1080/01944366908977225

Bandura, A. 1977. Social learning theory. Prentice-Hall, Englewood Cliffs, New Jersey, USA

Bandura, A., and R. H. Walters. 1963. Social learning and personality development. Holt, Rinehart, \& Winston, New York, New York, USA.

Barreteau, O. 2003. Our companion modelling approach. Journal of Artificial Societies and Social Simulation 6(2). [online] URL: http://jasss.soc.surrey.ac.uk/6/2/1.html

Barreteau, O., P. W. G. Bots, and K. A. Daniell. 2010. A framework for clarifying "participation" in participatory research to prevent its rejection for the wrong reasons. Ecology and Society 15(2): 1. [online] URL: http://www.ecologyands ociety.org/vol15/iss2/art1/

Beierle, T. C., and J. Cayford. 2002. Democracy in practice: public participation in environmental decisions. Resources for the Future, Washington, D.C., USA.

Beierle, T. C., and D. M. Konisky. 2000. Values, conflict, and trust in participatory environmental planning. Journal of Policy Analysis and Management 19(4):587-602. http://dx.do i.org/10.1002/1520-6688(200023)19:4<587::AID-PAM4>3.0. $\mathrm{CO} ; 2-\mathrm{Q}$

Belshaw, D., and R. Chambers. 1973. A management systems approach to rural development. Discussion paper, 161, Institute for Development Studies, University of Nairobi, Nairobi, Kenya. [online] URL: http://opendocs.ids.ac.uk/ope ndocs/bitstream/handle/123456789/76/rc135.pdf?sequence $=1$

Belton, V., and T. J. Stewart. 2002. Multiple criteria decision analysis: an integrated approach. Kluwer Academic Publishers, Norwell, Massachusetts, USA.

Berkes, F., and C. Folke, editors. 1998. Linking social and ecological systems: management practices and social mechanisms for building resilience. Cambridge University Press, New York, New York, USA.

Biggs, S., and G. Smith. 1998. Beyond methodologies: coalition building for participatory technology development. World Development 26:239-248. http://dx.doi.org/10.1016/S0 $\underline{\text { 305-750X(97)10041-9 }}$
Bijlsma, R. M., P. W. G. Bots, H. A. Wolters, and A. Y. Hoekstra. 2011. An empirical analysis of stakeholders' influence on policy development: the role of uncertainty handling. Ecology and Society 16(1): 51. [online] URL: http: //www.ecologyandsociety.org/vol16/iss1/art51/

Borowski, I., J. Le Bourhis, C. Pahl-Wostl, and B. Barraqué. 2008. Spatial misfit in participatory river basin management: effects on social learning, a comparative analysis of German and French case studies. Ecology and Society 13(1): 7. [online] URL: http://www.ecologyandsociety.org/vol13/iss1/art7/

Bots, P. W. G., R. Bijlsma, Y. von Korff, N. Van der Fluit, and H. Wolters. 2011. Supporting the constructive use of existing hydrological models in participatory settings: a set of "rules of the game." Ecology and Society 16(2): 16. [online] URL: http://www.ecologyandsociety.org/vol16/iss2/art16/

Bousquet, F., O. Barreteau, C. Mullon, and J. Weber. 1996. Modélisation d'accompagnement: systèmes multi-agents et gestion des ressources renouvelables. In "Quel environnement au XXIème siècle? Environnement, maîtrise du long terme et démocratie." GERMES, Paris, France. [online] URL: http://c ormas.cirad.fr/pdf/accompagnement.pdf.

Brett, E. A. 1996. The participatory principle in development projects: the costs and benefits of cooperation. Public Administration and Development 16(1):5-19. http://dx.doi.or g/10.1002/(SICI)1099-162X(199602)16:1<5::AID-PAD854>3.3. $\mathrm{CO} ; 2-\mathrm{Y}$

Bryson, J. M. 2004. What to do when stakeholders matter: stakeholder identification and analysis techniques. Public Management Review 6(1):21-53. http://dx.doi.org/10.1080/14 $\underline{719030410001675722}$

Cahill, C., F. Sultana, and R. Pain. 2007. Participatory ethics: politics, practices, institutions. ACME: An international $e$ journal for critical geographies 6(3):304-318.

Carr, D. S., and K. Halvorsen. 2001. An evaluation of three democratic, community-based approaches to citizen participation: surveys, conversations with community groups, and community dinners. Society \& Natural Resources 14 (2):107-26. http://dx.doi.org/10.1080/089419201300000526

Chambers, R. 1994. Participatory rural appraisal (PRA): analysis of experience. World Development 22(9):1253-1268. http://dx.doi.org/10.1016/0305-750X(94)90003-5

Coglianese, C. 1997. Assessing consensus: the promise and performance of negotiated rulemaking. Duke Law Journal 46 (6):1255-1349. http://dx.doi.org/10.2307/1372989

Cornwall, A., and R. Jewkes. 1995. What is participatory research? Social Science \& Medecine 41(12):1667-1676. 
Costanza, R., and M. Ruth. 1998. Using dynamic modeling to scope environmental problems and build consensus. Environmental Management 22(2):183-195. http://dx.doi.org /10.1007/s002679900095

Creighton, J. L. 2005. The public participation handbook: making better decisions through citizen involvement. JosseyBass, San Francisco, California, USA.

Daniell, K. A., and N. Ferrand. 2006. Participatory modeling for water resources management and planning. Report D3.8.2. Aquastress Integrated Project, European Union Sixth Framework Programme, Brussels, Belgium.

Daniell, K. A., N. Ferrand, and A. Tsoukiàs. 2006. Investigating participatory modelling processes for group decision aiding in water planning and management. Proceedings of the International Conference on Group Decision and Negotiation. Universität Karlsruhe, Karlsruhe, Germany.

Daniell, K. A., I. White, N. Ferrand, I. S. Ribarova, P. Coad, J.-E. Rougier, M. Hare, N. A. Jones, A. Popova, D. Rollin, P. Perez, and S. Burn. 2010. Co-engineering participatory water management processes: theory and insights from Australian and Bulgarian interventions. Ecology and Society 15(4): 11. [online] URL: http://www.ecologyandsociety.org/vol15/iss4/ $\underline{\operatorname{art11/}}$

Delli Carpini, M., F. L. Cook, and L. R. Jacobs. 2004. Public deliberation, discursive participation, and citizen engagement: a review of the empirical literature. Annual Review of Political Science 7:315-344. http://dx.doi.org/10.1146/annurev.polisci .7 .121003 .091630

Delli Priscoli, J. 2004. What is public participation in water resources management and why is it important? Water International 29(2):221-227. http://dx.doi.org/10.1080/02508 $\underline{060408691771}$

Dietz, T., and P. C. Stern, editors. 2008. Public participation in environmental assessment and decision-making. Panel on Public Participation in Environmental Assessment and Decision Making, National Research Council, Washington, D.C, USA.

Enserink, B., M. Patel, N. Kranz, and J. Maestu. 2007. Cultural factors as co-determinants of participation in river basin management. Ecology and Society 12(2): 24. [online] URL: http://www.ecologyandsociety.org/vol12/iss2/art24/

Etienne, M., editor. 2010. La modélisation d'accompagnement: une démarche participative en appui au développement durable. Editions Quae, Versailles, France.

Fiorino, D. J. 1990. Citizen participation and environmental risk: a survey of institutional mechanisms. Science, Technology \& Human Values 15(2):226-243. http://dx.doi.org $\underline{110.1177 / 016224399001500204}$
Flood, R. L. 1998. Action research and the management and systems sciences. Systemic Practice and Action Research 11 (1):79-101. http://dx.doi.org/10.1023/A:1022917022601

Flood, R. L., and M. C. Jackson. 1991. Creative problem solving: total systems intervention. John Wiley \& Sons, Chichester, UK.

Folke, C., T. Hahn, P. Olsson, and J. Norberg. 2005. Adaptive governance of social-ecological systems. Annual Review of Environment and Resources 30:441-473. http://dx.doi.org/10 .1146/annurev.energy.30.050504.144511

Freire, P. 2003. Pedagogy of the oppressed. 30th anniversary edition. With an introduction by Donaldo Macedo. The Continuum International Publishing Group Inc. New York, New York, USA.

Gregory, W. J. 1996. Discordant pluralism: a new strategy for critical systems thinking. Systemic Practice and Action Research 9(6):605-625. http://dx.doi.org/10.1007/BF02169216

Gunderson, L. H., and C. S. Holling, editors. 2001. Panarchy: understanding transformations in human and natural systems. Island Press, Washington, D.C., USA.

Habermas, J. 1987. The theory of communicative action. Vol. 2. Lifeworld and system. A critique of functionalist reason. Beacon Press, Boston, Massachusetts, USA.

Hare, M., R. A. Letcher, and A. J. Jakeman. 2003. Participatory natural resource management: a comparison of four case studies. Integrated Assessment 4(2):62-72. http://dx.doi.org/1 $\underline{0.1076 / \text { iaij.4.2.62.16706 }}$

HarmoniCOP. 2005. Sustainability learning for river basin management and planning in Europe. Integration report. HarmoniCOP, University of Osnabrück, Osnabrück, Germany. [online] URL: http://www.abhatoo.net.ma/index.php/ fre/content/download/10910/177119/file/Sustainability_learn ing for water basin management.HarmoniCOP[1].pdf

Hatchuel, A. 2005. Towards an epistemology of collective action: management research as a responsive and actionable discipline. European Management Review 2:36-47. http://dx. doi.org/10.1057/palgrave.emr.1500029

Hatchuel, A., and H. Molet. 1986. Rational modeling in understanding and aiding human decision-making: about two case studies. European Journal of Operational Research 24:178-186. http://dx.doi.org/10.1016/0377-2217(86)90024-X

Heron, J. 1996. Co-operative inquiry: research into the human condition. Sage, London, UK.

Hirsch, D., G. Abrami, R. Giordano, S. Liersch, N. Matin, and M. Schlüter. 2010. Participatory research for adaptive water 
management in a transition country - a case study from Uzbekistan. Ecology and Society 15(3): 23. [online] URL: http://www.ecologyandsociety.org/vol15/iss3/art23/

Hoverman, S., H. Ross, T. Chan, and B. Powell. 2011. Social learning through participatory integrated catchment risk assessment in the Solomon Islands. Ecology and Society 16 (2): 17. [online] URL: http://www.ecologyandsociety.org/vol16/ iss $2 / \operatorname{art} 17 /$

Huitema, D., C. Cornelisse, and B. Ottow. 2010. Is the jury still out? Toward greater insight in policy learning in participatory decision processes- the case of Dutch citizens' juries on water management in the Rhine Basin. Ecology and Society 15(1): 16. [online] URL: http://www.ecologyandsociety. org/vol15/iss1/art16/

Huitema, D., E. Mostert, W. Egas, S. Moellenkamp, C. PahlWostl, and R. Yalcin. 2009. Adaptive water governance: assessing the institutional prescriptions of adaptive (co-) management from a governance perspective and defining a research agenda. Ecology and Society 14(1): 26. [online] URL: http://www.ecologyandsociety.org/vol14/iss 1/art26/

Irvin, R. A., and J. Stansbury. 2004. Citizen participation in decision making: is it worth the effort? Public Administration Review 64(1):55-65. http://dx.doi.org/10.1111/j.1540-6210.2 004.00346.x

Jakeman, A. J., R. A. Letcher, and J. P. Norton. 2006. Ten iterative steps in development and evaluation of environmental models. Environmental Modelling and Software 21(5):602-614. http://dx.doi.org/10.1016/j.envsoft.2 $\underline{006.01 .004}$

Johnson, C. J. 1997. Public participation and sustainable development: counting the costs and benefits. TDRI Quarterly Review 12(2):25-32.

Jones, N. A., P. Perez, T. G. Measham, G. J. Kelly, P. D'Aquino, K. A. Daniell, A. Dray, and N. Ferrand. 2009. Evaluating participatory modeling: developing a framework for cross-case analysis. Environmental Management 44:1180-1195. http://dx.doi.org/10.1007/s00267-009-9391-8

Klinke, A. 2009. Deliberate transnationalism — transnational governance, public participation and expert deliberation. Forest Policy and Economics 11(5-6):348-356. http://dx.doi. org/10.1016/j.forpol.2009.02.001

Kuper, M., M. Dionnet, A. Hammani, Y. Bekkar, P. Garin, and B. Bluemling. 2009. Supporting the shift from state water to community water: lessons from a social learning approach to designing joint irrigation projects in Morocco. Ecology and Society 14(1): 19. [online] URL: http://www.ecologyandsociety. org/vol14/iss1/art19/

Laird, F. N. 1993. Participatory analysis, democracy, and technological decision making. Science, Technology, \&
Human Values 18(3):341-361. http://dx.doi.org/10.1177/0162 $\underline{24399301800305}$

Lamers, M., B. Ottow, G. Francois, and Y. von Korff. 2010. Beyond dry feet? Experiences from a participatory watermanagement planning case in The Netherlands. Ecology and Society 15(1): 14. [online] URL: http://www.ecologyandsociety. org/vol15/iss1/art14/

Lebel, L., J. M. Anderies, B. Cambell, C. Folke, S. HatfieldDodds, T. P. Hughes, and J. Wilson. 2006. Governance and the capacity to manage resilience in regional social-ecological systems. Ecology and Society 11(1): 19. [online] URL: http:// www.ecologyandsociety.org/vol11/iss1/art19/

Lee, K. N. 1993. Compass and gyroscope. Integrating politics and science for the environment. Island Press, Washington, D. C., USA.

Lee, K. N. 1999. Appraising adaptive management. Ecology and Society 3(2): 3. [online] URL: http://www.ecologyandso ciety.org/vol3/iss2/art3/

Lewin, K. 1939. Field theory and experiment in social psychology: concepts and methods. American Journal of Sociology 44(6):868-896. http://dx.doi.org/10.1086/218177

Lewin, K. 1951. Field theory in social science. Harper and Row, New York, New York, USA.

Loucks, D. P., J. Kindler, and K. Fedra. 1985. Interactive water resources modeling and model use: an overview. Water Resources Research 21(2):95-102. http://dx.doi.org/10.1029/ WR021i002p00095

Luna-Reyes, L. F., I. J. Martinez-Moyano, T. A. Pardo, A. M. Cresswell, D. F. Andersen, and G. P. Richardson. 2006. Anatomy of a group model-building intervention: building dynamic theory from case study research. System Dynamics Review 22(4):291-320. http://dx.doi.org/10.1002/sdr.349

Marks, J. S. 2004. Negotiating change in urban water management: attending to community trust in the process. Pages 203-215 in T. Daniell, R. James, and K. Takara, editors. Cities as catchments-WSUD2004. Proceedings of the 2004 International Conference on Water Sensitive Urban Design, 21-24 November, Adelaide, South Australia. Engineers Australia, Canberra, Australia.

Mazri, C. 2007. Apport méthodologique pour la structuration de processus de décision publique en contexte participatif. Le cas des risques industriels majeurs en France. UFR Sciences des Organisations. Université Paris Dauphine, Paris, France.

Méndez, P. F., N. Isendahl, J. M. Amezaga, L. Santamaría. 2012. Facilitating transitional processes in rigid institutional regimes for water management and wetland conservation: experience from the Guadalquivir Estuary. Ecology and Society 17(1): 26. http://dx.doi.org/10.5751/ES-04494-170126 
Midgley, G. 1997. Developing the methodology of TSI: from oblique use of methods to creative design. Systemic Practice and Action Research 10:305-319. http://dx.doi.org/10.1007/B F02557900

Midgley, G. 2000. Systemic intervention: philosophy, methodology, and practice. Kluwer Academic/Plenum, New York, New York, USA.

Mingers, J. 2001. Multimethodology - mixing and matching methods. Pages 289-309 in J. Rosenhead and J. Mingers, editors. Rational analysis for a problematic world revisited: problem structuring methods for complexity, uncertainty and conflict. John Wiley \& Sons, Chichester, UK.

Mingers, J. 2003. A classification of the philosophical assumptions of management science methods. Journal of the Operational Research Society 54(6):559-570. http://dx.doi.or g/10.1057/palgrave.jors.2601436

Moellenkamp, S., M. Lamers, C. Huesmann, S. Rotter, C. Pahl-Wostl, K. Speil, and W. Pohl. 2010. Informal participatory platforms for adaptive management. Insights into niche-finding, collaborative design, and outcomes from a participatory process in the Rhine basin. Ecology and Society 15(4): 41. [online] URL: http://www.ecologyandsociety.org/v ol15/iss4/art41/

Mostert, E. 2003. The challenge of public participation. Water Policy 5(2):179-197.

Mostert, E., C. Pahl-Wostl, Y. Rees, B. Searle, D. Tàbara, and J. Tippett. 2007. Social learning in European river-basin management: barriers and fostering mechanisms from 10 river basins. Ecology and Society 12(1): 19. [online] URL: http://W ww.ecologyandsociety.org/vol12/iss1/art19/

Muro, M., and P. Jeffrey. 2012. Time to talk? How the structure of dialog processes shapes stakeholder learning in participatory water resources management. Ecology and Society 17(1): 3. http://dx.doi.org/10.5751/ES-04476-170103

Newig, J. 2005. Die Oeffentlichkeitsbeteiligung nach der EGWasserrahmenrichtlinie: Hintergruende, Anforderungen und die Umsetzung in Deutschland. Zeitschrift fuer Umweltpolitik und Umweltrecht 28(4):469-512.

Newig, J. 2007. Does public participation in environmental decisions lead to improved environmental quality? Communication, Cooperation, Participation (International Journal of Sustainability Communication) 1(1):51-71.

Newig, J., and O. Fritsch. 2009. Environmental governance: participatory, multi-level - and effective? Environmental Policy and Governance 19(3):197-214. http://dx.doi.org/10.1 002/eet.509
Ostrom, E. 1990. Governing the commons: the evolution of institutions for collective action. Cambridge University Press, Cambridge, UK.

Ostrom, E., J. Burger, C. Field, R. B. Norgaard, and D. Policansky. 1999. Revisiting the commons: local lessons, global challenges. Science 284:278-282. http://dx.doi.org/10. 1126/science.284.5412.278

Pahl-Wostl, C. 2007. Transitions towards adaptive management of water facing climate and global change. Water Resources Management 21(1):49-62. http://dx.doi.org/10.1007/ $\underline{\mathrm{s} 11269-006-9040-4}$

Pahl-Wostl, C., M. Craps, A. Dewulf, E. Mostert, D. Tàbara, and T. Taillieu. 2007. Social learning and water resources management. Ecology and Society 12(2): 5. [online] URL: http://www.ecologyandsociety.org/vol12/iss2/art5/

Pahl-Wostl, C., and M. Hare. 2004. Processes of social learning in integrated resource management. Journal of Community and Applied Social Psychology 14:193-206. http: //dx.doi.org/10.1002/casp.774

Pahl-Wostl, C., E. Mostert, and D. Tàbara. 2008a. The growing importance of social learning in water resources management and sustainability science. Ecology and Society 13(1): 24. [online] URL: http://www.ecologyandsociety.org/v ol13/iss $1 / \operatorname{art} 24 /$

Pahl-Wostl, C., J. Newig, and D. Ridder. 2008b. Linking public participation to adaptive management. Pages 150-173 in Philippe Quevauviller, editor. Groundwater science \& policy. An international overview. Springer, Berlin, Germany.

Pateman, C. 1970. Participation and democratic theory. Cambridge University Press, Cambridge, UK.

Probst, K., and J. Hagmann. 2003. Understanding participatory research in the context of natural resource management - paradigms, approaches and typologies. Network Paper No. 130. Overseas Development Institute Agricultural Research \& Extension Network (AgREN), London, UK.

Reason, P., and W. R. Torbert. 2001. The action turn: toward a transformational social science. Concepts and Transformation 6(1):1-37. http://dx.doi.org/10.1075/cat.6.1.02rea

Renn, O., T. Webler, and P. Wiedemann, editors. 1995. Fairness and competence in citizen participation: evaluating models for environmental discourse. Kluwer Academic Publishers, Dordrecht, The Netherlands.

Ridder, D., E. Mostert, and H. A. Wolters, editors. 2005. Learning together to manage together: improving participation in water management. University of Osnabrück, Osnabrück, Germany. 
Rijsberman, F. R. 2006. Water scarcity: fact or fiction? Agricultural Water Management 80(1-3):5-22. http://dx.doi.o rg/10.1016/j.agwat.2005.07.001

Rittel, H. W. J., and M. M. Webber. 1973. Dilemmas in a general theory of planning. Policy Siences 4:155-169. http://d x.doi.org/10.1007/BF01405730

Rogers, C. 1961. On becoming a person: a therapist's view of psychotherapy. Constable, London, UK.

Röling, N. 1996. Towards an interactive agricultural science. European Journal of Agricultural Education and Extension 2:35-48. http://dx.doi.org/10.1080/13892249685300061

Röling, N. 2002. Beyond the aggregation of individual preferences: moving from multiple to distributed cognition in resource dilemmas. Pages 25-47 in C. Leeuwis and R. Pyburn, editors. Wheelbarrows full of frogs: social learning in rural resource management. Royal Van Gorkum, Assen, The Netherlands.

Rosenhead, J., J. and Mingers. 2001. Rational analysis for a problematic world revisited: problem structuring methods for complexity, uncertainty and conflict. John Wiley \& Sons, Chichester, UK.

Rowe, G., and L. J. Frewer. 2000. Public participation methods: a framework for evaluation. Science, Technology, \& Human Values 25(1):3-29. http://dx.doi.org/10.1177/0162243 $\underline{90002500101}$

Rowe, G., and L. J. Frewer. 2004. Evaluating public participation exercises: a research agenda. Science, Technology, \& Human Values 29(4):512-556. http://dx.doi.or $\mathrm{g} / 10.1177 / 0162243903259197$

Rowe, G., R. Marsh, and L. J. Frewer. 2001. Public participation methods: evolving and operationalizing an evaluation framework; final report to the Department of Health and Health and Safety Executive. Institute of Food Research, Norwich, UK.

Rowe, G., R. Marsh, and L. J. Frewer. 2004. Evaluation of a deliberative conference using validated criteria. Science, Technology, \& Human Values 29(1):88-121. http://dx.doi.org /10.1177/0162243903259194

Schein, E. H. 1999. Kurt Lewin's change theory in the field and in the classroom: notes toward a model of managed learning. Reflections: The Society for Organizational Learning Journal 1(1):59-74. http://dx.doi.org/10.1162/1524 $\underline{17399570287}$

Schuett, M. A., S. W. Selin, and D. S. Carr. 2001. Making it work: keys to successful collaboration in natural resource management. Environmental Management 27(4):587-593. http://dx.doi.org/10.1007/s002670010172
Selman, P., C. Carter, A. Lawrence, and C. Morgan. 2010. Reconnecting with a neglected river through imaginative engagement. Ecology and Society 15(3): 18. [online] URL: http://www.ecologyandsociety.org/vol15/iss3/art18/

Senge, P., A. Kleiner, C. Roberts, R. Ross, G. Roth, and B. Smith. 1999. The dance of change: the challenges to sustaining momentum in learning organizations. Doubleday, New York, New York, USA.

Senge, P., A. Kleiner, C. Roberts, R. B. Ross, and B. J. Smith. 1994. The fifth discipline fieldbook. Strategies and tools for building a learning organization. Nicholas Brealey, London, UK.

SLIM Project. 2004. Social learning as a policy approach for sustainable use of water; a field-tested framework for observing, reflecting and enabling. The Open University, Milton Keynes, UK. [online] URL: https://sites.google.com/site/ slimsociallearningforiwm/research-outcomes/policy-briefs-1/ SLIMFrameworkSocalLearningJune04.pdf?attredirects $=0 \& \mathrm{~d}=1$

Stern, P. C., and H. V. Fineberg, editors. 1996. Understanding risk: informing decisions in a democratic society. National Academy Press, Washington, D.C., USA.

Stringer, L. C., A. J. Dougill, E. Fraser, K. Hubacek, C. Prell, and M. S. Reed. 2006. Unpacking "participation" in the adaptive management of social-ecological systems: a critical review. Ecology and Society 11(2): 39. [online] URL: http:// www.ecologyandsociety.org/vol11/iss2/art39

Sultana, F. 2007. Reflexivity, positionality and participatory ethics: negotiating fieldwork dilemmas in international research. ACME: An International E-Journal for Critical Geographies 6(3):374-385.

Syme, G. J., and B. E. Nancarrow. 2002. Evaluation of public involvement programs: measuring justice and process criteria. Water 29(4):18-24.

Tàbara, J. D., and C. Pahl-Wostl. 2007. Sustainability learning in natural resource use and management. Ecology and Society 12(2): 3. [online] URL: http://www.ecologyandsociety.org/vol12/ iss $2 / \mathrm{art} 3 /$

Taket, A. R., and L. A. White. 1996. Pragmatic pluralism - an explication. Systemic Practice and Action Research 9 (6):571-586. http://dx.doi.org/10.1007/BF02169214

United Nations Development Programme (UNDP). 2006. Beyond scarcity: Power, poverty and the global water crisis. Human Development Report 2006. UNDP, New York, New York, USA.

Uphoff, N., J. Cohen, and A. Goldsmith. 1979. Feasibility and application of rural development participation: a state of the 
art paper. Cornell University Press, Ithaca, New York, New York, USA.

van den Belt, M., editor. 2004. Mediated modeling: a system dynamics approach to environmental consensus building. Island Press, Washington, D.C., USA.

Vennix, J. A. M. 1996. Group model building: facilitating team learning using system dynamics. John Wiley \& Sons, Chichester, UK.

Voinov, A., and F. Bousquet. 2010. Modelling with stakeholders. Environmental Modelling \& Software 25:1268-1281. http://dx.doi.org/10.1016/j.envsoft.2010.03.007

von Korff, Y., P. d'Aquino, K. A. Daniell, and R. Bijlsma. 2010. Designing participation processes for water management and beyond. Ecology and Society 15(3): 1. [online] URL: http://www.ecologyandsociety.org/vol15/iss3/ art1/

Walker, B., and D. Salt. 2006. Resilience thinking. Island Press, Washington, D.C., USA.

Walters, C. 1986. Adaptive management of renewable resources. Macmillan, New York, New York, USA.

Webler, T. 1995. "Right" discourse in citizen participationan evaluative yardstick. Pages 35-86 in O. Renn, T. Webler, and P. M. Wiedemann, editors. Fairness and competence in citizen participation-evaluating models for environmental discourse. Kluwer Academic, Dordrecht, The Netherlands.

Webler, T. 1999. The craft and theory of public participation: a dialectical process. Journal of Risk Research 2(1):55-71. http://dx.doi.org/10.1080/136698799376989

Webler, T., and O. Renn. 1995. A brief primer on participation: philosophy and practice. Pages 17-33 in O. Renn, T. Webler, and P. M. Wiedemann, editors. Fairness and competence in citizen participation-evaluating models for environmental discourse. Kluwer Academic, Dordrecht, The Netherlands. http://dx.doi.org/10.1007/978-94-011-0131-8_2

Webler, T., and S. Tuler. 2001. Public participation in watershed management planning. Human Ecology Review 8 (2):29-39.

Werick, W. J., and W. Whipple, Jr. 1994. Managing water for drought: national study of water management during drought. IWR Report 94-NDS-8. US Army Corps of Engineers, Water Resources Support Centre, Institute for Water Resources, Alexandria, Virginia, USA. [online] URL: http://www.iwr.us ace.army.mil/docs/iwrreports/94nds8.pdf

Zorrilla, P., G. Carmona, Á. De la Hera, C. Varela-Ortega, P. Martínez-Santos, J. Bromley, and H. Jorgen Henriksen. 2009. Evaluation of bayesian networks as a tool for participatory water resources management: application to the Upper
Guadiana Basin in Spain. Ecology and Society 15(3): 12. [online] URL: http://www.ecologyandsociety.org/vol15/iss3/ $\underline{\operatorname{art12l}}$ 